\title{
Histone H3 Gene Mutation
}

National Cancer Institute

\section{Source}

National Cancer Institute. Histone H3 Gene Mutation. NCI Thesaurus. Code C154306.

A change in the sequence of a histone $\mathrm{H} 3$ family gene. 